ROCZNIKI HUMANISTYCZNE

Tom LXIX, zeszyt 3 - 2021

DOI: http://doi.org/10.18290/rh21693-7

AGATA WOJCIECHOWSKA

\title{
MĄŻ BYWAŁY? \\ ODYSEUSZ JAKO POKUTUJĄCY HOMO RATIONALIS \\ W PODRÓŻACH DO PIEKIEŁ BOLESŁAWA MICIŃSKIEGO
}

Wybitny poznański krytyk Konstanty Troczyński zarzucił Bolesławowi Micińskiemu w recenzji jego Podróży do piekiet zbyt poetycki i zmetaforyzowany styl, podczas gdy od filozofa wymaga się „,surowej myśli, biegnącej szybko ścieżynami rozumowań do przeczuwanego wniosku" (125). Jak zauważa Łukasz Wróbel, krytyk oskarża autora o „stylistyczny snobizm, nieskonkretyzowany układ treści [...], estetyczny stosunek do tematu oraz troskę o styl miast logiczne dowodzenie" (291). Właściwie Troczyński skrytykował filozofa za to, że ten odważył się napisać esej, a nie rozprawę bądź traktat. Faktycznie, Miciński nie zastanawia się nad historią pojęcia piekła, nad jego ontologicznym statusem, nawet go wprost nie definiuje. Piekła, przez które podróżuje swą myślą eseista, nie są jednakowe, pochodzą z różnych czasów, a najważniejszy w nich jest człowiek. Pierwszą figurą w Podróżach do piekiet jest Odyseusz, który dla Micińskiego staje się zarówno pretekstem do rozważań o myśleniu i człowieku, jak i prototypem człowieka rozumnego w ogóle. Co ciekawe, postać króla Itaki, uwikłana w poddany krytyce przez Troczyńskiego zmetaforyzowany i zawiły styl, zyskuje nowe oblicze, które pozwoli Micińskiemu wykorzystać ją do konkretnych celów - ukazania istotności myślenia humanistycznego. W rozważaniach towarzyszą filozofowi dwie „formy” myślowe. Pierwszą jest psychologia głębi, drugą natomiast klasycyzm - obie mają decydujący wpływ na sposób interpretacji postaci Odyseusza, maja jednak - co należy podkreślić już na wstępie - charakter mocno zindywidualizowany, dopasowany do potrzeb i wizji Micińskiego.

Mgr Agata WojciechowsKa - absolwentka MISH na Uniwersytecie Jagiellońskim w Krakowie, doktorantka na Wydziale Polonistyki Uniwersytetu Jagiellońskiego - przygotowuje rozprawą doktorską dotyczącą eksperymentalizmu myślenia w modernizmie europejskim; e-mail: agatacdziuba@gmail.com; ORCID: https://orcid.org/0000-0003-1555-2126. 
$\mathrm{Z}$ tego względu, zanim analizie zostanie poddany sam Odyseusz, należy przyjrzeć się zarówno klasycyzmowi, jak i psychoanalizie jako metodom, formom myślenia zaproponowanych przez eseistę. Oba te elementy mają kluczowe znaczenie dla późniejszego odczytania postaci Odyseusza w interpretacji Micińskiego.

Jerzy Kwiatkowski w bardzo popularnej serii historii literatury polskiej oświadcza, że to właśnie psychologizm jest głównym trzonem myśli Micińskiego, a nie erudycyjna wartość esejów (485). Podobnie ten problem opisuje Roma Kwiecień, która uważa dwie dominujące sfery zainteresowań Micińskiego, czyli klasycyzm i psychoanalizę, za wykluczające się wzajemnie, choć prowadzące do czegoś nowego w myśli krytycznej eseisty. Mówienie jednak o twórczości filozofa jako pogłębieniu myśli psychoanalitycznej bądź przyporządkowanie go modnemu w dwudziestoleciu nurtowi klasycyzującemu ogranicza bardzo możliwości interpretacji jego tekstów ${ }^{1}$. Celem niniejszego artykułu będzie więc nie tylko próba wnikliwej analizy postaci Odyseusza w eseju Podróże do piekiet, ale także ukazanie, że twórczość Micińskiego ma ponadczasowy charakter i stanowi "filozoficzne widowisko" (Wyka 414)2. Esej ten można określić jako próbę dotarcia do istoty podmiotowości czy po prostu powrotu do świata.

Dla Micińskiego psychoanaliza nie była jedynie narzędziem do badania literatury, ale przede wszystkim miała służyć lepszemu zrozumieniu samego siebie. Dlatego też oprócz bycia wielkim propagatorem myśli Freuda, był także jej krytykiem:

Każde dzieło artystyczne jest nie tylko przedmiotem bezpośrednich wzruszeń, ale i podstawą bezpośredniej nadbudowy psychicznej, podstawą pracy, w której konstruujemy sami siebie, a my - $\mathrm{w}$ tym, co $\mathrm{w}$ nas wartościowe - jesteśmy właśnie sumą tych wrażeń. (Miciński, „Pamięć” 254)

Wyraźne są tutaj dwa elementy istotne dla całej myśli Micińskiego. Pierwszym z nich jest szeroko humanistyczne pojmowanie dzieła artystycznego istotnego dla człowieczeństwa w ogóle, drugim natomiast podkreślenie sposobu kształtowania swojej podmiotowości poprzez pracę porównaną tutaj

\footnotetext{
${ }^{1}$ Zbigniew Ambrożewicz (82) zauważa, że Bolesław Miciński za francuskim psychoanalitykiem Charles'em Beaudoinem porównuje psychoanalizę do klasycyzmu.

${ }^{2}$ Filozoficznym widowiskiem nazywa eseje Micińskiego Kazimierz Wyka: „Eseje swoje osadza Miciński na prawie że dziewiczym u nas pograniczu literatury i filozofii. [...] Stany i interpretacje, wykwitając na tym pograniczu, znajdują w Micińskim wyjątkowo czułego i erudycyjnego różdżkarza. Widowisko filozoficzne... Jakiś moralitet filozoficzny ponad czasy i kultury wzniesiony [...]" (414-415).
} 
do twórczego konstruowania. Wydaje się, że właśnie te dwa elementy są dla filozofa w psychoanalizie najważniejsze. Daje ona możliwość wglądu w człowieka, nie wystarcza jednak do uchwycenia jego istoty. W interpretacji Romy Kwiecień, która podąża za myślą zarówno Carla Junga, jak i Amy Maud Bodkin, Odyseusz w esejach Micińskiego staje się archetypem. Filozof „studiuje tematy, które wykazują tendencję do przetrwania w życiu wspólnoty lub rasy, i porównuje rozmaite formy, jakie przybierają archetypy, analizując reakcję poszczególnych osób" (Bodkin 572). Wydaje się jednak, że zainteresowanie postacią Odyseusza nie wynika z fascynacji Jungiem i jego metodą. Wręcz przeciwnie, psychoanalizę $\mathrm{w}$ tym przypadku Miciński traktuje bardzo wybiórczo i instrumentalnie, jest ona metodą wtórną wobec jego klasycyzmu, który - jak to już zostało nadmienione - również jest przez eseistę wypracowany w sposób indywidualistyczny.

Nie lubimy psychoanalizy, która jest niczym innym, jak aparatem Roentgena skierowanym na ludzką duszę i ujawniającym nieubłaganie niemile dla człowieka prawdy. (...) Jeśli więc mamy pokonać zło, którym wszyscy jesteśmy obarczeni (...), musimy je poznać, a psychoanaliza właśnie jest (...) wywiadem, który przedziera się do sztabu wroga. (Miciński, „Zagadnienia psychoanalizy” 2)

Jak widać w powyższym fragmencie, rewizjonistyczny i doktrynalny charakter psychoanalizy nie odpowiadał Micińskiemu, uważał ją za swego rodzaju „wywiad”, który można zastosować w odpowiednich warunkach, ale nie należy za nim ślepo podążać. Jest to jednak jedno $z$ wielu spojrzeń eseisty na psychoanalizę. Zbigniew Ambrożewicz stwierdził, że stosunek Micińskiego do metody Freuda cechował się „wieloznacznością i nieustannym ewoluowaniem" (67), dlatego też trudno wyłonić z prac Micińskiego jednoznaczną wizję psychologii głębi. Opinia Micińskiego fluktuuje, w każdej jednak jego pracy poświęconej psychoanalizie można znaleźć zarówno jej osiągnięcia, jak i jej niekonsekwencje. Przede wszystkim filozof nie zgadzał się na to, by człowiek był istotą poddaną deterministycznym prawom (71). Oskarża Freuda o podważenie podstaw człowieczeństwa. Jak zauważa Ambrożewicz: „świadomość zdeterminowana zostaje bowiem przez popędy tkwiące w nieświadomości, co uzależnia - uznawany przecież za istotę człowieczeństwa - intelekt od zwierzęcych instynktów" (74). Badacz podkreśla jednak to, że Miciński nie był tylko krytykiem koncepcji Freuda. Widział w niej bowiem świadectwo epoki oraz, co wydaje się dla myśli polskiego eseisty szczególnie istotne, pewien sposób widzenia człowieka i jego świata (69). Z kolei Zofia Rosińska w Psychoanalitycznym myśleniu o sztuce powiązała rozumienie psychoanalizy 
przez Micińskiego z „myśleniem egoicznym” (96). Ma ono, według badaczki, charakter apolliński, w którym dominuje tendencja estetyczna i przywiązanie wagi do pracy świadomości.

Obok psychologii głębi w centrum zainteresowań Micińskiego stawiany jest przez badaczy klasycyzm. Podobnie jak psychoanaliza przybiera on w rozważaniach filozofa specyficzną formę:

(...) klasycyzmu nie można zawiesić w próżni, nie można przejść nad otchłanią osobowości, bo wtedy klasycyzm jest pusty i bez pokrycia, bo jest jak nie wypełniony schemat fugi. Trzeba najpierw zobaczyć, jaką bestią jest człowiek, żeby móc to dopiero ograniczać. Goethe mówił: „romantycy - to chorzy; klasycy to zdrowi”. Ja bym powiedział: „klasycy to uzdrowieni chorzy”. Inaczej: „klasycy to romantycy, którzy przełamali swoją chorobę: tak zwaną „potrzebę nieskończoności”, „amorfizm”, „szczyt chaosu” itd. To łatwo nie być w szponach swojej osobowości, kiedy się jej nie zna. Poznać ją, wyrwać się, zdusić bestię, zmusić ją, żeby dobrze jeszcze działała - to jest właśnie sztuka. (...) z jednej strony mój klasycyzm jest wyrazem mego ,ja romantycznego" i treść jego wiążę bez reszty z erotycznymi tendencjami dzieciństwa (nagie rzeźby, Hera - Matka i bo ja wiem, co) - z drugiej (...) jest wyrazem mego ,ja klasycznego", skierowany jest przeciw tendencjom popędowym i wyraża się w rygoryzmie, ograniczeniu, dezindywidualizacji itd. (Miciński, Pisma 417-422)

Klasycyzm filozofa przybiera formę ,przepracowanego" romantyzmu, jest poddany silnym rygorom myślowym, ciągłemu ograniczaniu i „tresowaniu" myśli. Warte uwagi jest również to, że dla Micińskiego w centrum zainteresowań klasycyzmu stać powinien człowiek, i to nie człowiek byle jaki, ale ten, którego cechuje rozumność. To, w jaki sposób eseista traktuje zarówno psychoanalizę, jak i klasycyzm, ma znaczący wpływ na to, jak kształtuje się w jego rozważaniach postać Odyseusza.

Dla Micińskiego Odyseja nie stanowi reliktu czasów minionych, ale też nie pisze on wprost o jej uniwersalizmie. Jest świadomy, że tylko konkretny czytelnik początku XX wieku dojrzy w tragizmie eposu „spiętrzone trudności i konflikty naszego czasu" (Miciński, Podróże do piekiet 16). Ta uwaga stanowi sedno klasycyzmu Micińskiego, który przede wszystkim ma na celu przepracowanie intelektualne dorobku kulturowego starożytności grecko-rzymskiej tak, aby móc z niego wydobyć prawdę o człowieku współczesnym.

Klasycyzm przesłania twarz człowieka i obnaża czystą, obiektywną ideę tragizmu. Jej „mroczna poświata” nie załamana w pryzmacie osobowości ślizga się po maskach tragicznych, modeluje niezmienny wykrój ust, leży plamą cienia w głęboko żłobionych oczodołach i połyskuje odbita w szumiącym morzu Odysei. (Miciński, Podróże do piekiet 20) 
Rygoryzm klasycyzmu Micińskiego ma więc na celu odsłonięcie prawdy o człowieku, zdjęcie zasłony, a prawdą Odyseusza dla filozofa jest jego tragizm. Interesująca w powyższym fragmencie jest tajemnica, która towarzyszy zmetaforyzowanemu stylowi eseisty. Myśliciel musi pokonać mroki, pryzmaty i plamy cienia, aby móc przy pomocy swojego rozumu wydobyć Odyseusza na światło dziennie. Wydaje się, że właśnie ten fragment rozważań Micińskiego w doskonały sposób zdradza, co eseista faktycznie robi $\mathrm{z}$ bohaterem Homera - modeluje go jak rzeźbiarz swoje dzieło.

Najważniejszą decyzją w rozważaniach filozofa jest nazwanie przez niego Odyseusza ,przemądrym”:

Klasycyzm osiąga więc realność przez prawidłową strukturę formy oraz na drodze repryz, które płynnej i zmiennej rzeczywistości nadają walor egzystencji, pedantycznie akcentując cechy, przysługujące niezmiennie ludziom i rzeczom. Penelopa jest „, cnotliwa”, jutrzenka jest „różano-palca”. Odyseusz jest „przemądry”. (Miciński, Podróże do piekieł 43)

Wydawałoby się, że ten wybór jest uzasadniony, jako że faktycznie

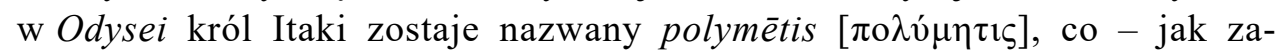
uważa Krystyna Stawecka - zostało słusznie przetłumaczone zarówno przez Józefa Wittlina, jak i Jana Parandowskiego jako „przemądry” (Stawecka 9596). W ten sposób uniknęli tworzenia „rażących neologizmów, czy też niezwykłych sformułowań". Jasność przekazu, dzięki której polski czytelnik może sprawnie powiązać epitet z postacią, jest dla Staweckiej ogromną wartością polskiego tłumaczenia. Tak też Miciński buduje swoją interpretację na uznaniu, że Odyseusz jest w dziele Homera „przemądrym”.

Mądrość jest istotą Odyseusza, jest „substancją”, dokoła której osadzają się „,echy”: przelotny gniew, płacz, połysk oka. (...) Odys jest jakby ucieleśnieniem arystotelesowskiej definicji człowieka, „człowiek jest stworzeniem rozumnym”. (Miciński, Podróże do piekiet 43-45)

Miciński podkreśla, że sztuka idealizuje rzeczywistość i tym samym zaciera pewne jednostkowe cechy: takie, które mają charakter przypadkowy (Miciński, Podróże do piekiet 45). Stąd też wynika wyrazistość epiteton ornans Odyseusza, który staje się w oczach filozofa pochwałą potęgi rozumu. Myślenie jest tą zdolnością, która wyróżnia człowieka spośród innych istot, dlatego też Odyseusz jest herosem najbliższym człowiekowi. Co ciekawe, właśnie w tym momencie wyraźne jest tworzenie przez Micińskiego

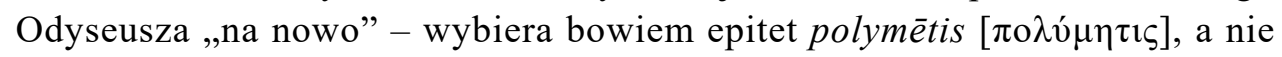




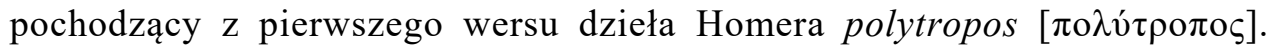
Wojciech Ryczek w swojej niezwykle dogłębnej analizie językoznawczej udowadnia, że to właśnie ,politropiczność” stanowi stały epitet Odyseusza (339). Badacz stwierdza, że to ta cecha „zawiera w sobie wszystkie pozostałe określenia, które można uznać za pochodne względem niego", w tym

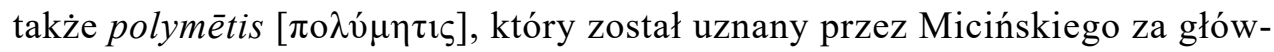
ny epitet Odysa. Bohater Homera nosi więc przydomek polytropos [ $[\pi \mathrm{o} \lambda v$ $\tau \rho о \pi \circ \varsigma]$, który w thumaczeniach figuruje jako „przebiegły”. Jak zauważa Jonathan Culler: „dosłownie oznacza jednak «wielopostaciowy»; określa się on wszakże poprzez ustawiczną walkę o ocalenie siebie i towarzyszących mu żeglarzy oraz powrót do rodzinnej Itaki” (127). Wielopostaciowość Odyseusza to nie tylko jego spryt, ale także wszystko to, co jest związane z przedrostkiem ,poly-”, co świadczy o sławie bohatera Homera. Politropiczność obejmuje bowiem trzy sfery życia i działalności Odyseusza, czyli: podróż, poznanie, cierpienie (wiele wędrował, wielu ludzi i miast poznał, wiele wycierpiał) (Ryczek 338). Czy wybór, jakiego dokonał Bolesław Miciński, kiedy uznał epitet „przemądry” za przydomek Odyseusza, ogranicza w jakiejś mierze jego interpretację? I tak, i nie. Z jednej strony faktycznie rezygnuje on z owej wielości oblicz Odyseusza, ale jednak nie unika konfrontacji z żadną z trzech sfer życia, o których pisze Ryczek. Po drugie, w tłumaczeniu Wittlina, z którego Miciński korzystał, epitet polytropos

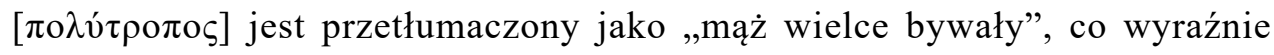
nie ma takich konotacji jak grecki oryginał. Jak zauważa Józef Korpanty, tłumaczenie Wittlina nie jest nieprawdziwe, ponieważ faktycznie w kolejnych wersach Odysei czytamy „o jego podróżach i nabytym doświadczeniu życiowym" (197). Wyraźnie jednak widać, że nie ma mowy o sprycie, przebiegłości czy „obrotności” Odyseusza ${ }^{3}$. Nic dziwnego więc, że Miciński zdecydował się na wybór innego przydomka dla króla Itaki, jakim jest epitet „przemądry”.

Warto jednak nadmienić, że w ogóle postać Odyseusza już w antyku traktowano jako personifikację różnych, często bardzo rozbieżnych, idei głównych szkół filozoficznych (Montiglio 20-24). Bohater Homera na prze-

\footnotetext{
${ }^{3} \mathrm{~W}$ thumaczeniu Jana Parandowskiego polytropos [ $\left.\pi \mathrm{o} \lambda \dot{\tau} \rho \circ \mathrm{o}_{\mathrm{o}}\right]$ zostaje przełożony na „mąż wielce obrotny", co - jak podkreśla Józef Korpanty - jest najcelniejszym odpowiednikiem greckiego oryginału. Aby poprzeć swoją tezę, badacz powołuje się na łacińskie tłumaczenie Liwiu-

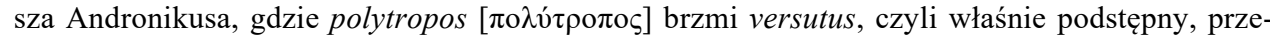
biegły, obrotny. Oczywiście Korpanty w żaden sposób nie ujmuje tłumaczeniu Wittlina wartości czy kunsztu, wskazuje jednak na pewną nieścisłość, która mimo że nie ma wpływu na oddanie stylu dzieła, to jednak mija się z semantyką oryginału. Zob. Korpanty 192-197.
} 
strzeni wieków zyskiwał tyle konkretyzacji, ile było o nim ludzkich wyobrażeń. O tym zjawisku pisze Jan Parandowski:

Jakby wstąpił w niego duch Proteusa, Odys zmieniał się w ciągu wieków nieustannie. W Rzymie nie miał dobrej sławy, tylko stoicy owijali go w pochlebne alegorie, w średniowiecznym Roman de Troie był nikczemnym intrygantem, u Szekspira w Troilus i Kressyda makiawelistycznym politykiem. (...) Niezliczone są metamorfozy Odyssa, w jednej z nich nawiedził on wyobraźnię Wyspiańskiego. (34-35)

W rozważaniach Bolesława Micińskiego Odyseusz stał się więc mędrcem. Co ciekawe, nie jest to pierwsze takie spojrzenie w historii. Silvia Montiglio zauważa, że to właśnie w okresie wczesnej nowożytności Odyseusz przybiera postać mędrca, stanowi bowiem wcielenie cnoty oraz pragnienia wiedzy i mądrości (148-156). Może właśnie na tym polega jedna $\mathrm{z}$ konsekwencji politropiczności tego bohatera, że w zależności od potrzeb epoki zmienia on swoje oblicze.

Odyseja tak jak Iliada jest dla Micińskiego epopeją czynu. Czynem, który skazuje Odyseusza na tułaczkę, jest oślepienie Polifema. Nie jest to wina moralna, taka nie ma bowiem wartości tragicznej. Micińskiemu jednak to nie wystarcza. Eseista odbiera Odyseuszowi wygląd herosa, porównuje go do stracha na wróble, starca, który o kiju wędruje $\mathrm{z}$ dala od domu (Miciński, Podróże do piekiet 27-28). Król Itaki staje się królem biedaków, śmieszny i smutny zarazem, taki ma być według filozofa „koźlonogi” symbol tragiczności. Odbiera mu wygląd herosa, ale nie oznacza to, że obdziera go z heroizmu, wręcz przeciwnie - heroizm króla Itaki realizuje się w afirmacji rzeczywistości tragicznej (Miciński, Podróże do piekiet 31). Jest on spotęgowany decyzją odrzucenia daru nieśmiertelności z rąk Kalipso; daru, który zdawałby się nie do odrzucenia dla każdego innego śmiertelnika. Miciński wyraźnie podkreśla, że prawdziwym heroizmem nie jest ani pragnienie sławy, której Achilles w zaświatach przecież żałuje, czy osiągnięcie boskiego statusu poprzez nieśmiertelność, ale właśnie zdecydowanie się na życie, i to na życie ukierunkowane na śmierć. To stanowi o wyjątkowości Odyseusza jako człowieka - odwaga wobec życia ku śmierci. Ta myśl eseisty znakomicie wpisuje się w filozofię niemieckiego myśliciela Martina Heideggera, dla którego „bycie-ku-śmierci” (niem. Sein-zum-Tode) stanowiło o wyjątkowości istotowej egzystencji bytu. Oczywiście należy podkreślić, że myśl Heideggera jest późniejsza wobec rozważań Bolesława Micińskiego, wydaje się jednak, że zestawienie tych dwóch koncepcji nie tylko zwiększa możli- 
wości interpretacyjne zawiłej drogi myślowej polskiego eseisty, ale także, a może przede wszystkim, wskazuje na istotne dla epoki tendencje w myśleniu o podmiotowości. Heidegger podkreślał, że to właśnie śmierć jest tylko „moja”, przez co „umieranie to nie zdarzenie, lecz fenomen, który należy rozumieć egzystencjalnie, i to w pewnym szczególnym, wymagającym jeszcze bliższego wyodrębnienia siebie" (Heidegger 303). Śmierć więc nie tylko stanowi o naszej podmiotowości, ale także nadaje sens egzystencji w ogóle. Co więcej, śmierć nie ma znaczenia negatywnego, pozwala ona spojrzeć nam i zmierzać ku naszemu własnemu jestestwu (Heidegger 304). Stąd rezygnacja Odyseusza z nieśmiertelności jest jednym z kroków umożliwiającym samopoznanie. Znów Miciński dokonuje pewnej dosyć istotnej zmiany. Źródłem sławy Odyseusza czyni bowiem jego odważne zmaganie się z tragizmem. Natomiast sam bohater, przedstawiając się na uczcie Alkinoosa, króla tajemniczego ludu Feaków, ujawnia źródło swej sławy:

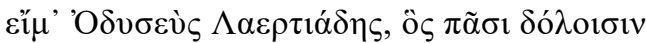

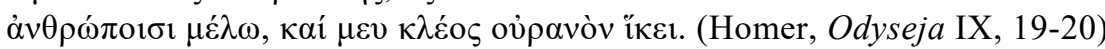

Odyseusz chlubi się więc tym, że znany jest z „wszelakich fortelów”, czyli znowu z czynów, które świadczą o jego sprycie. Zofia Abramowiczówna z kolei zaznacza we wstępie do Odysei, że stałym epitetem bohatera jest

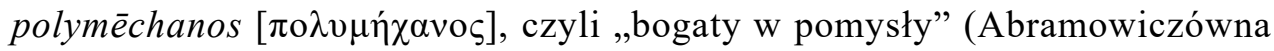
IX). Źródłem sławy Odyseusza dla Micińskiego staje się jednak jego „potęga rozumu", i to stanowczo rozumiana nie jako dobór odpowiednich środków do sytuacji, ale właśnie rozwaga, namysł i świadome dążenie ku śmierci.

Właśnie te przymioty utracił człowiek nowożytny, który nie ma odwagi zejść do piekieł i poznać samego siebie. Jan Kott, odwołując się do myśli Micińskiego, podkreślał, że zastosowaną przez eseistę psychologię głębi można traktować jako pewien użyteczny mit o człowieku, co wydaje się chyba najważniejsze, mit humanistyczny (Kott 3-4). Właśnie ten humanistyczny wymiar myślenia wyłania się z esejów Micińskiego i stanowi o wyjątkowości jego twórczości. Odyseusz nie jest więc po prostu archetypem na modłę Jungowską, jest podstawą mitu o człowieku, jest pierwowzorem człowieka, człowieka myślącego - homo rationalis. „[...] mądry Odyseusz jest wzorem i prototypem człowieka, który jest istotą rozumną" (Miciński, Podróże do piekiet 45). Jest tym, który w nowożytności zaginął i należy go wydobyć ze źródeł kultury antycznej, będącej podstawą całej myśli humanistycznej.

Cechą charakterystyczną Odysei jest, według filozofa, wszechpanująca śmierć, czy to pod postacią Hermesa, tajemniczego ludu Feaków, czy w końcu 
wędrówki Odyseusza do krainy umarłych. Zofia Abramowiczówna nazywa podróż bohatera w zaświaty „katabazą”, choć jednocześnie przyznaje, że jest ona specyficzna, ponieważ nie polega na zajściu do podziemi, czyli ruchu w dół, a na przepłynięciu przez ocean (Abramowiczówna IX). „Odyseja rozwinęła się z mitu eschatologicznego i dlatego podróż do piekieł jest kulminacyjnym punktem wędrówki Odyseusza” (Miciński, Podróże do piekieł 26). Kwintesencję samopoznania Odyseusza ma stanowić, według eseisty, dowiedzenie się o swojej śmierci. Ten, kto poznał śmierć, poznał samego siebie. „Bycie ku śmierci” w dziele Homera nie ma jednak dla Micińskiego charakteru niszczącego, podobnie jak u Heideggera - w negatywizmie na sposób dialektyczny tkwi ogromna wartość - tu jest nią mądrość.

Wędrówka Odyseusza musi zakończyć się aktem pokuty. Jak zauważa Zofia Ambrowiczówna:

Musi on bowiem przejednać Posejdona w sposób wyrażony tu w formie zagadki: ma wędrować tak daleko z wiosłem na ramieniu, aż ktoś powie, że on niesie szuflę do wiania zboża (w przekładzie: łopatę), tzn. nie widział nigdy wiosła. Wtedy ma wbić je w ziemię i złożyć ofiary Posejdonowi, czyli ustanowić jego kult wśród ludzi nieznających morza. (Abramowiczówna XXVIII-XXIX)

Należy zauważyć, że samo proroctwo Tejrezjasza stanowi motto dla całego zbioru esejów i jest dla Micińskiego główną tajemnicą o Odyseuszu. Dla filozofa owa przepowiednia nie dotyczy jedynie przyszłości bohatera, ale stanowi o jego samopoznaniu, jest zwieńczeniem drogi poznawczej wędrowca. Podróż Odyseusza ma dla Micińskiego wymiar mistyczny. „Poznać przyszłość, to znaczy: poznać mechanizm namiętności skłębionych w marzeniu sennym - zstąpić do piekieł" (Miciński, Podróże do piekieł 100). Aby lepiej zrozumieć myśl eseisty, w której przyszłość łączy ze śmiercią i samopoznaniem, warto przywołać myśl Heideggera:

Tym, co wytrzymuje wyróżnioną możliwość, co w jej obrębie pozwala sobie na przyjście do siebie, jest pierwotny fenomen przyszłości. Jeśli byciu jestestwa przysługuje właściwe bądź niewłaściwe bycie ku śmierci, to jest ono możliwe tylko jako przyszłe (...). „Przyszłość” nie oznacza tu jakiegoś „teraz”, które nie stało się jeszcze „rzeczywiste” i dopiero się takim stanie - lecz szłość (Kunft), z jaką jestestwo na podstawie swej najbardziej własnej możności bycia przychodzi do siebie. (Heidegger 409)

Przyszłość jest więc kolejnym składnikiem samopoznania. Dlatego też to proroctwo Tejrezjasza staje się dla Micińskiego kluczowe w jego wędrówce. Mądrość król Itaki zdobywa więc dzięki nie samej podróży, ale temu, co się 
z nią wiąże, czyli tragizmowi, nastawieniu na śmierć i wiedzy o swej przyszłości. Dla Micińskiego jednak nie jest to pełen obraz dążenia Odyseusza ku samowiedzy, brakuje jeszcze jednego elementu, który jest dla filozofa najważniejszy i decydujący - pokuty.

(...) pokutna podróż „przemądrego” Odyseusza w głąb kraju „gdzie ręka ludzka soli przenigdy do strawy nie sypie", prowadzi do doliny Józefata [...] Odys odprawi pokutne ofiary, stąd też rozpocznie drogę powrotną już nie jako „przemądry”, ale jako „Pobożny” wędrowiec - jako Eneasz. (Miciński, Podróże do piekiet 50-51)

Poprzez złożenie ofiary wędrówka Odyseusza staje się pokutą. Bohater wkracza do świata umarłych, dokonuje swoistej „katabazy”, odpokutowując swą winę, staje się ,pobożnym”. Jest człowiekiem nawróconym.

Jak zauważa Alexander C. Loney, na taką interpretację nie wskazuje jedynie eschatologiczny sens całej Odysei, ale także jedno słowo użyte przez Alkinoosa będące określeniem podróży króla Itaki, czyli: pompe [ $\pi \mathrm{\rho} \mu \pi \hat{]}]$, które można przetłumaczyć jako „procesja”, „uroczysty pochód” (Loney 32-34). Odnalezienie nieba stanowi u Micińskiego najpiękniejszy akt woli człowieka, ale też jest owiany tajemnicą. Co ciekawe, filozof ukazuje przeobrażenie Odyseusza w Eneasza, co oczywiście nie oznacza, że ci dwaj bohaterowie są dla eseisty tą samą osobą (Miciński, Podróże do piekiet 51). Obaj są jednak pierwowzorem człowieka rozumnego, o ile jednak Odyseusz musiał do swej pobożności dotrzeć, o tyle Eneasz wyrusza w swoją podróż już ukształtowany. Tu znowu Miciński dokonuje jednak pewnego przesunięcia. Faktycznie, Eneasz nazywa siebie pobożnym (pius), Wergiliusz jednak wyraźnie włożył w jego usta słowa Odyseusza. Jak już zostało wspomniane, król Itaki przedstawia siebie podczas uczty wydanej u Alkinoosa

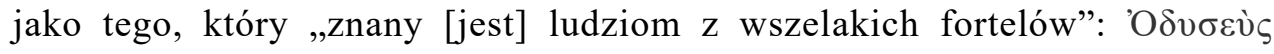

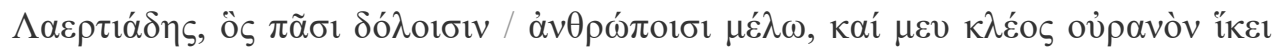
(Homer, Odyseja IX, 19-20). Z kolei Eneasz przedstawia się w następujący sposób: „Sum pius Aeneas, raptos qui ex hoste Penates / classe veho mecum, farma super aethera notus" (Wergiliusz, Eneida I, 378-379). Przy zestawieniu obu tych wypowiedzi widać, że Wergiliusz podmienił politropiczność Odyseusza na pobożność Eneasza. Cecha rzymskiego bohatera nie zastępuje więc „mądrości” Odyseusza, którą na myśli miał Miciński. Na tym przykładzie znakomicie widać konstrukcję rozważań filozofa. Eseista tak naprawdę kreuje Odyseusza na postać samodzielną, funkcjonującą poza tekstem antycznym. 
Dla Micińskiego homo rationalis stanowi nie tylko podstawę kultury antycznej, ale też pomost pomiędzy dwoma światami - greckim i rzymskim. Nawet jeśli filozof dokonał pewnych nadużyć, wpisują się one znakomicie w jego metodę i odpowiadają jego spojrzeniu na klasycyzm. Wydaje się, jakoby Odyseusz Micińskiego bliższy był Nestorowi niż podstępnemu żołnierzowi, który brał udział w wojnie trojańskiej. Odyseusz w eseju Micińskiego na powrót staje się mitem, ale mitem człowieka rozumnego, doskonałego pierwowzoru, który ma nas poprowadzić ku lepszemu zrozumieniu humanistycznej podmiotowości. Specyficzne podejście zarówno do klasycyzmu, jak i psychoanalizy ukazuje mocno zindywidualizowany sposób rozumowania Micińskiego. Tak jak z klasycyzmu i psychoanalizy wybrał odpowiadające mu elementy w celu stworzenia własnych koncepcji, tak też z dzieła Homera wydobywa swojego Odyseusza. Gdyby eseista obrał za główną cechę króla Itaki jego „obrotność”, wówczas nie mógłby ukazać go jako pierwowzoru potęgi rozumu, a wtedy Odyseusz nie mógłby nas, ludzi współczesnych, ocalić. To świat antyczny dał nam myślenie humanistyczne i choć może brzmieć to banalnie, to jednak droga do odzyskania prawdziwego myślenia wcale nie jest łatwa. Miciński dopiero na koniec swoich esejów, które prowadzą go przez różne ludzkie piekła, widzi nadzieję i spogląda w niebo. W to niebo, które dla Heideggera jest źródłem brania miary, w które tylko poeci mogą prawdziwie patrzeć i widzieć Boga. Dla Micińskiego dopiero Kartezjusz, który uważając, że „dobrze sądzić, oznacza dobrze czynić”, odnalazł niebo. Pytanie jednak, czy i antyczny bohater nie dokonał tego, składając ofiarę Posejdonowi i tym samym odważnie przypieczętowując swój los.

\section{BIBLIOGRAFIA}

Abramowiczówna, Zofia. „Wstęp”. Homer. Odyseja. Tłum. Lucjan Siemieński, Wydawnictwo Ossolineum, 1981.

Ambrożewicz, Zbigniew. Esej filozoficzny Bolesława Micińskiego jako sposób poszukiwania podstaw realności świata. Wydawnictwo Uniwersytetu Opolskiego, 2003.

Bodkin, Maud, A. „Wzorce archetypowe w poezji tragicznej”. Tłum. Przemysław Mroczkowski. Teoria badań literackich za granica, t. 2, red. Stefania Skwarczyńska, Wydawnictwo Literackie, 1974.

Culler, Jonathan. Teoria literatury. Tłum. Maria Bassaj, Prószyński i S-ka, 2002.

Heidegger, Martin. Bycie i czas. Tłum. Bogdan Baran, Wydawnictwo Naukowe PWN, 2013.

Homer. Odyseja - Homer. Odyssey. Perseus, http://www.perseus.tufts.edu/hopper/text?doc=Perseus \%3Atext\%3A1999. 01.0135\%3 Abook\%3D9\%3Acard\%3D1. Dostęp 05.05.2020. 
Korpanty, Józef. „Zapomniany tłumacz Odysei Homerowej”. Przektadaniec, nr 18-19, 2007, ss. 192-197.

Kott, Jan. „Spacer po piekłach”. Pion, nr 8, 1938.

Kwiatkowski, Jerzy. Dwudziestolecie międzywojenne. Wydawnictwo Naukowe PWN, 2008.

Loney, Alexander C. „Pompē in the 'Odyssey”". The Epic Journey in Greek and Roman Literature, red. Thomas Biggs i Jessica Blum, Cambridge University Press, 2019, ss. 31-58.

Miciński, Bolesław. „Pamięć”. Pisma zebrane, t. 2: Treść i forma. Artykuły i recenzje, red. Paweł Kądziela, Biblioteka „WIĘZI”, 2011, ss. 354-355.

Miciński, Bolesław. Pisma. Eseje, artykuty, listy. Wybór i oprac. Anna Micińska, Wydawnictwo Znak, 1970.

Miciński, Bolesław. Podróże do piekiet. Prosto z mostu, 1937.

Montiglio, Silvia. From Villain to Hero. Odysseus in Ancient Thought. The University of Michigan Press, 2011.

Parandowski, Jan. „Wstęp”. Homer. Odyseja. Tłum. Jan Parandowski, Czytelnik, 1972.

Rosińska, Zofia. Psychoanalityczne myślenie o sztuce. PWN, 1985.

Ryczek, Wojciech. „Politropia: retoryka Odyseusza”. Teksty Drugie, nr 5, 2015, ss. 336-356.

Stawecka, Krystyna. „Dwa polskie przekłady Odysei. Odyseja w thumaczeniu Parandowskiego i Wittlina”. Roczniki Humanistyczne, t. 9, z. 2, 1960, ss. 93-102.

Troczyński, Konstanty. „Uroki pięknego stylu. Przyczynek do dziejów snobizmu”. Dziennik Poznański, nr 85, 13 kwietnia 1938. Cytat za: Konstanty Troczyński. Pisma wybrane, oprac. Stanisław Dąbrowski, t. 2, Wydawnictwo Literackie, 1998, s. 7.

Wergiliusz. Eneida - P. Vergili Maronis Aeneidos Liber Primvs. The Latin Library, https:// www.thelatinlibrary.com/vergil/aen1.shtml. Dostęp 05.05.2020.

Wróbel, Łukasz. Hylé noesis: Trzy międzywojenne koncepcje literatury stosowanej. Wydawnictwo Naukowe Uniwersytetu Mikołaja Kopernika, 2013.

Wyka, Kazimierz. „Podróże do piekieł”. Stara szuflada i inne szkice z lat 1932-1939, oprac. Maciej Urbanowski, Wydawnictwo Literackie, 2000.

\section{MĄŻ BYWAŁY? \\ ODYSEUSZ JAKO POKUTUJACY HOMO RATIONALIS \\ W PODRÓŻACH DO PIEKIEŁ BOLESŁAWA MICIŃSKIEGO}

\section{Streszczenie}

Celem artykułu jest dokonanie analizy postaci Odyseusza wykreowanej w Podróżach do piekiel Bolesława Micińskiego, a także ukazanie, że twórczość Micińskiego ma ponadczasowy charakter i stanowi wybitny przykład eseju filozoficznego. Za kluczowe w interpretacji eseisty uważa się jego rozumienie klasycyzmu i psychoanalizy, które mają charakter instrumentalny i służą odkryciu prawdy o Odyseuszu. Głównym trzonem analizy eseju Micińskiego jest przyjęty przez niego epiteton ornans „przemądry”, który narzuca postrzeganie Odyseusza jako nie przebiegłego żołnierza, ale mędrca. Odyseusz w eseju Micińskiego na powrót staje się mitem, ale mitem człowieka rozumnego, doskonałego pierwowzoru, który ma nas poprowadzić ku lepszemu zrozumieniu humanistycznej podmiotowości.

Słowa kluczowe: Odyseusz; Bolesław Miciński; homo rationalis; politropiczność; klasycyzm. 


\section{WORLDLY MAN? \\ ODYSSEUS AS A PENITENT HOMO RATIONALIS \\ IN THE "JOURNEYS TO HELL” BY BOLESŁAW MICIŃSKI}

Summary

The aim of the article is the analysis of Odysseus in Bolesław Miciński's essay Podróże do piekiet ("Journeys to Hell"). The main purpose is to show that the philosopher creates a new Odysseus described by specific epiteton ornans which underlines wisdom not the cunning of Homer's hero. What is more, Miciński builds his vision of Odysseus using psychoanalysis and his own understanding of classicism. He treats these two perspectives as instruments to extract particular features of Odysseus. Miciński is building a new myth of Odysseus, the myth of homo rationalis, perfect ratio which can save the humanistic subjectivity in the $\mathrm{XX}^{\text {th }}$ century.

Key words: Odysseus; Bolesław Miciński; homo rationalis; polytropos, classicism. 